\title{
AleXANDR MaCUHIN*
}

\section{Overall Trends in the Migration Processes in the Republic of Moldova: the Mills of the God Grinding Slowly?}

\begin{abstract}
This paper discusses the key characteristics of the migration situation and overall trends in the migration processes in the Republic of Moldova. Practically, many of the former Soviet republics were faced with serious social and economic problems. Economical systems of new post-soviet countries were ill-equipped to handle new borders and customs barriers. As the "multi-national state" was dissolved, the majority of new post-Soviet states struggled with ethnic conflicts, which triggered the first wave of the so-called "great escape" of the population. In Moldova's case, the Transnistrian conflict was a classic example of such a civilizational crisis, the solution to which was not found to date. The first wave of the "great escape" was triggered by the hard situation of the national identity formation. The "second wave" was a reaction to an increasingly poor economic situation. Today, the formation of the "third wave of great escape" becomes increasingly more evident - perhaps the last one for the Moldavian state. This "third wave" is also connected with integrational processes, mostly in the European Union countries. The second part of the article analyses the relationship between the economic development of the Republic of Moldova and the current migration situation. In general, despite a number of positive changes, such as the reduction of the critical high level of dependence of the economy on financial remittances of Moldovan migrant workers, the level of such dependence remains very high, and the speed of development of the Moldovan economy, on the contrary, is significantly reduced. The paper concludes with four main factors that, in the author's opinion, are critical for the analysis of the current negative migration situation in the Republic of Moldova, as well as those that may become key factors that will have a significant impact on the
\end{abstract}

* PhD Political Science, Adam Mickiewicz University, Faculty of Political Science and Journalism, alexmacuhin@gmail.com; ORCID: 0000-0003-2627-255X. 
strengthening of the negative socio-economic situation in the country and the systemic crisis in the future 2035-2040.

Key words: Republic of Moldova, labor migration, remittances, GDP, demography, integration, European Union, Eastern Partnership.

JEL Classification: F22

It can be stated that the phenomenon of mass labor migration has largely become a "lifeline" for a significant percentage of the population of the former Soviet republics and the Republic of Moldova is not an exception. The unfolding global economic crisis, exacerbated by factors such as economic problems and political instability in Moldova, causes mounting economic pressure on the population. As a result, increasingly more Moldavians choose the path of labor migration or leave the country permanently to settle in other regions.

During the period when Moldova was one of the USSR republics, it was subject to union-wide laws, under which movement of the population beyond the Soviet borders was regulated through a restrictive system of exit visas. The system failed after the launch of the "perestroika" policy. One of its consequences was the liberalization of migration legislation in the field of ethnic repatriation. The changes in legislation also affected the (at that time) Moldovan Soviet Socialist Republic. The first to take advantage of the newly liberalized migration policy were mainly ethnic Jews and Germans, as well as members of their families, repatriating to Israel and Germany respectively (Mosneaga, 249). It is worth mentioning that these tendencies intensified in the first years after the Republic of Moldova gained full independence.

After 1991 and the collapse of the Soviet Union, the Republic of Moldova faced serious problems in the field of interethnic policy, given the course taken by the new government for maximum rapprochement with neighboring Romania. The basis was the geopolitical project of "Great Romania", according to which it was supposed to create a new unitary state of "one Romanian people". Such a political agenda was, for a variety of reasons, unacceptable both for the majority of national minorities and for a part of the new state's majority ethnic group, which eventually led to a series of armed clashes and a territorial division of the country (called the "Transnistrian conflict"), which, however, did not turn into a conflict exclusively of an inter-ethnic nature. However, the migration consequences of the country's split have not been fully studied, as it is no longer possible to obtain accurate data on the exact number of people who left Moldovan territory during the conflict and as a result of it. In 
general, it is believed that the armed clashes on the Dniester River resulted in the outflow of a certain percentage of Moldova's population to countries such as Russia and Ukraine, and this wave of migration was most likely ethnic in nature. Besides, the post-conflict year of 1993 became the year of the most mass exodus of the Jewish diaspora of Moldova - according to various estimates, within a year the country was left by 3 to 4.5 thousand people of Jewish origin, which is more than the current number of ethnic Jews in the country, according to the latest census (Cojuchari, How Moldova became home to different peoples).

In general, it can be stated that during the formation of the independent Republic of Moldova, from 1993 to 1997, the vast majority of the migration flow (about 97\% of official emigrants) was made up of people leaving for permanent residence, as a rule - under the programs of state repatriation (in the case of Israel or Germany), or in other post-Soviet states also on ethnic principle - in the case of Ukraine, Russia and partially Belarus (Poalelungi, 218).

Table 1: Main migration and economic characteristics of the Republic of Moldova following the results of 2019

\begin{tabular}{|c|c|}
\hline Real (permanent residence) population & 2,68 billion \\
\hline NET migration rate (per thousand) & -15.6 migrants $/ 1,000$ population \\
\hline Population under 15 years & $16,04 \%$ \\
\hline Medium age of the population (both genders) & 38,7 years \\
\hline Medium age for males & 36,9 years \\
\hline Medium age for females & 40,3 years \\
\hline Medium fertile rate & 1,81 (for the live-born childs) \\
\hline Dependency ratio $^{1}(0-14+65+$ ages for $15-59$ ages $)$ & 65,8 \\
\hline Official part of the financial remittances in $2019^{2}$ & 1,91 USD billion \\
\hline
\end{tabular}

Source: Extended Migration Profile of the Republic of Moldova 2010-2015: Overview of Migration Trends for the Period 2005-2015, Analytical Report, Chisinau, 2017

An organized and steadily growing process of materially motivated migration began to dominate quantitatively in the second half of the 1990s. The main reasons for this growth were the unfavorable economic situation in the country, steadily

1 The dependency ratio is an age-population ratio of those peoples not in the labor force (ages 0-14 and $65+$ ) and those typically in the labor force (the productive part ages 15 to 64 ). It is used to measure the pressure on the productive population.

2 For most post-Soviet countries, where the level of financial transfers is a critical factor in GDP formation, it is worth considering the fact that there are not only official money transfer channels (banks, money transfer systems, other financial services), but also informal channels, such as direct money transfers from person to person, the use of various intermediaries and, to a lesser extent, smuggling. 
low GDP growth rates, as well as the emerging crisis of "superfluous people" caused by the general tendencies of economic contraction and liquidation of the majority of industrial and agro-industrial enterprises by the middle of the 90s, where jobs were not replaced by any alternatives. The final results of this process became apparent already in the period 1997-1998 when industrial output collapsed by $50 \%$, agricultural output fell by $25 \%$, and export figures also collapsed by $50 \%$ (Pantiru, Black, page 43). The default of 1998 in the Russian Federation, the traditional most important economic partner of Moldova, aggravated the economic situation in the country, pushing a considerable part of the population of the republic beyond the edge of extreme poverty. Under these conditions, the migration flows of the Moldovan population began to change - from ethnic repatriation to economically motivated migration.

The first wave of such migration was the pendular commercial migration (but not emigration, it was only a circular process), which consisted of periodic trips of Moldovan citizens to get cheap goods and their subsequent resale on the domestic market. However, by the end of the $90 \mathrm{~s}$, the tightening of the border crossing regime and the establishment of relative price parity led to the actual disappearance of this type of movement (Mosneaga, page 160). Due to these changes, commercial migration in Moldova has almost ceased as a species. And since 1999 and till today the basis of the whole migration flow of Moldovan citizens is labor migration - both organized and illegal.

Equally interesting is the distribution of migrants by country. In this case, we can talk about the presence of clear and stable trends in the preferences of migrants from certain countries (see Figure 1). For example, the Russian Federation is the undisputed leader in terms of the number of Moldovan migrants arriving, and Italy is also traditionally the "second place". At the same time, it is especially important to note that according to the definition of the National Bureau of Statistics of the Republic of Moldova, a Moldovan citizen is recognized (and, accordingly, is counted) as a migrant if he spends 6 months or more outside of Moldova. Also, students, undergraduates and postgraduates arriving in other countries on student visa and educational agreements are not counted as migrants, even though some analysts believe that at least 75 percent of students abroad make every effort to stay in the country of study and obtain official status there. For a similar reason, these statistics do not show real migration flows to countries such as the United States and Canada. However, the Moldavian mass-media repeatedly raised the question that the majority of Moldovan students who travel to the U.S. for summer work and study under the 
umbrella of the popular program "Work and Travel" and finally about one third of Moldovan students participating in the program will never return to Moldova again. (Investigatii.md 2008).

Figure 1: Distribution of Moldavian immigrants by country of residence (common medium rate for 2012-2016)

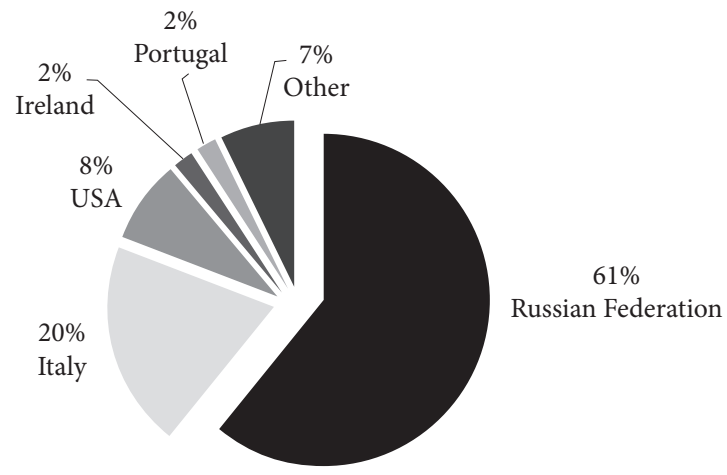

Source: Bilateral Estimates of Migrant Stocks Matrix in 2017, The World Bank Group, visualized by author, https:// www.worldbank.org/en/topic/migrationremittancesdiasporaissues/brief/migration-remittances-data

It should be noted that in statistical research in the field of migration and related problems, there are several serious methodological problems, such as the prevalence of a mechanical, descriptive approach, the lack of analysis of data obtained, and in some cases - the use of contradictory categories of research, for example, in the clear separation of the categories of "migrant" "tourist", "repatriate", "student", etc. Also, since 2013, the Moldovan press periodically publishes materials that question and seriously criticize the official data provided by the National Bureau of Statistics of the Republic of Moldova (Infotag.md 2016, Newsmaker.md 10.10.2019, Newamaker. md 18.12.2019).

Speaking about the political and social effects of the migration situation in Moldova, it is necessary to highlight the contribution of labor migrants to the Gross Domestic Product (GDP) of Moldova, as well as the acceptable level of prosperity of all Moldovan citizens in general. Remittances from migrant workers account for at least a third of Moldova's GDP, which in monetary terms amounted to about USD 1.4 billion in 2014, which puts Moldova in the third place in terms of dependence on remittances from abroad, among all post-Soviet republics. Only Tajikistan (about $40 \%$ of GDP) and Kyrgyzstan (about 35\% of GDP) remain more dependent. 
Figure 2: Proportion of remittances to annual GDP, Top-10 dependent countries at 2017

\section{The Countries Who Depend On Remittances The Most}

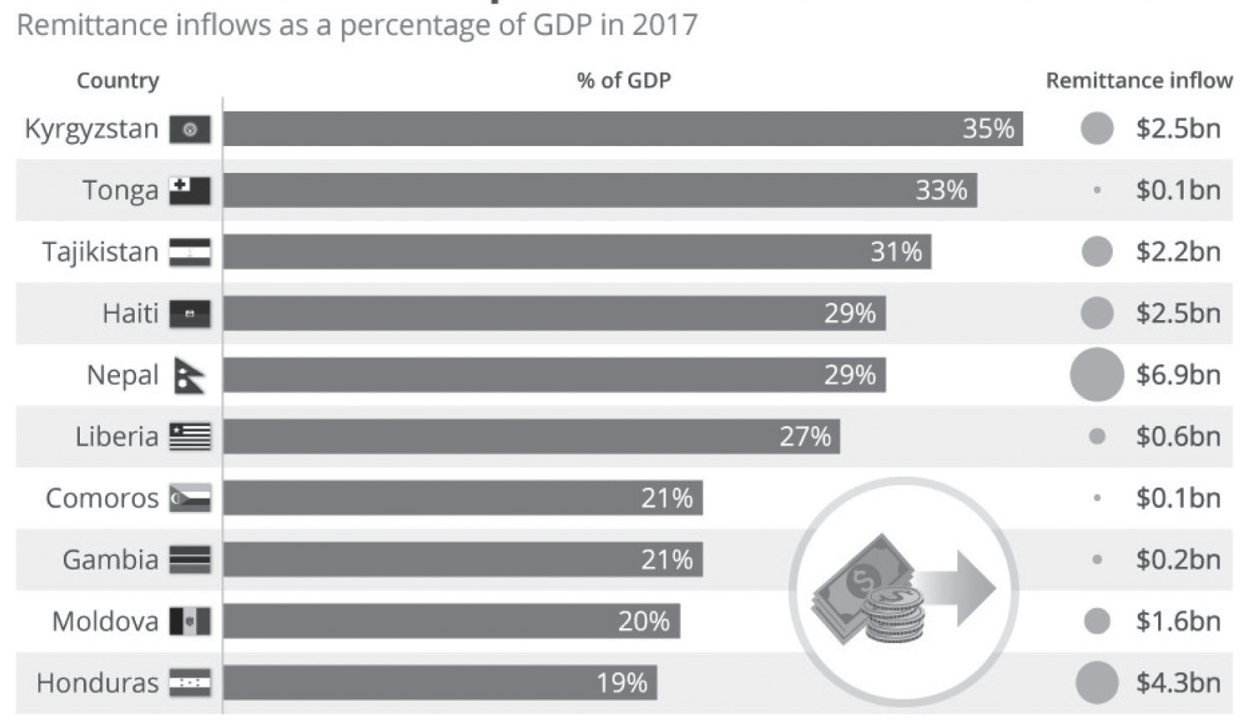

Source: Migration and Development Brief 29: Data and Demographics Labor Migration Return Migration and Reintegration Remittances, April 2018, World Bank Group

As it can be seen from the presented data, the high level of dependence of the Moldovan economy on regular financial remittances is a chronic problem. In addition, it should be taken into account that the monitoring data provided by the World Bank, as a rule, do not take into account additional volumes of financial resources transported (transferred) without the participation of public banking and other financial services, whose share, according to different estimates, is additionally from 10 to $20 \%$ of official statistics amount. Moreover, the frequency and comparative volume of this kind of "invisible transfers", both independently and through representatives of transport companies, as well as the ramified network of the Moldovan diaspora tend to increase for the traditional holidays - first of all Orthodox and Catholic Easter (April), equally for Orthodox and Catholic Christmas and New Year's Eve (late December - early January), as well as for the beginning of the school year in Moldova (late August - early September). 


\section{Figure 3: The share of remittances in comparison with the GDP rate in Republic of Moldova GDP}

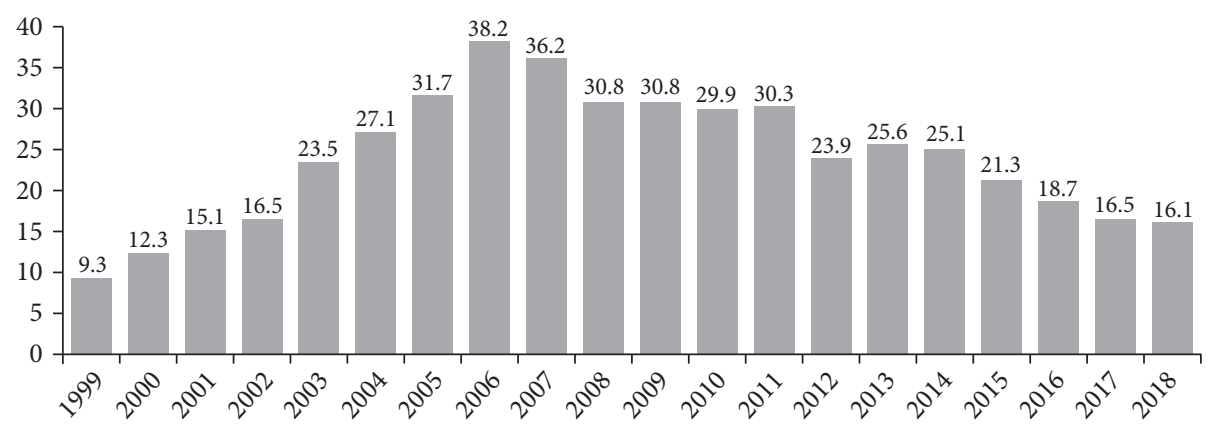

Source: National Bank of the Republic of Moldova, Graphical analysis of money transfers from abroad in favour of individuals, https://www.bnm.md/en/content/graphical-analysis-money-transfers-abroad-favour-individualsdecember-2018

Thus, such a serious financial dependence nevertheless allows maintaining a certain level of social stability, provided that the real level of income of the majority of the population within the country is practically not growing. Accordingly, the social role of a labor migrant within the country is changing - this status from "forced" to the social status of "respected people" who do real business because they work abroad and make a career there, as a person who left the country and returned from there with a certain amount of money (almost always tens of times more than he or she could earn inside the country) begins to be perceived as the mainstay of any family or household (Mosneaga, 46). However, there is a downside to this process, which is to increase the social stratification between "migrant" and "non-migrant" families. The understanding of the objective fact that almost no labor will allow even a relatively equal income level to that of an "average" migrant periodically leads to social conflicts. On the whole, this situation intensifies migration sentiments among the population, since the stereotype of a "successful migrant" is not opposed to any other image.

When comparing the experience of the Moldovan state with other countries in a similar situation, it can be noted that Moldova is moving almost in a beaten track of economically weak and politically unstable countries, where the main focus is on forced labor migration. At the same time, most of the income received from such migration, both by the state and individuals, is spent only on "eating" - that is, providing food, services, and entertainment, as well as stimulating retail trade. There is virtually no fundamental investment in the productive sectors of the economy through emigrant financing. In the end, it is safe to say that by the time the global 
financial crisis unfolded, the Republic of Moldova had approached with an extremely inefficient social and economic model. In this model, the main source of income has already been perceived mainly as "migrant financing", rather than income generated within the state. Other characteristics of this model are the significant excess of imports over exports (due to the development of services and retail chains) and the change in the demographic structure of the population, which is reflected in a sharp decline in fertility (especially given the fact that in some European Union member states the birth of a child in the territory of the country greatly facilitates the naturalization process for both the child and his or her parents). It should also be taken into account that mass labor migration affects not only the economic system of the state but also all social and political values in society, as well as the personal attitudes of each individual as a whole. This model of the public organization has revealed all its shortcomings with the unfolding of the global financial crisis. Thus, World Bank experts noted that any reduction in the volume and number of financial transfers very quickly affects the poverty level of the population. Margaret Marlett, the World Bank's leading economist for Moldova, said that "the global financial and economic crisis has shown that Moldova should think about another model of economic development" (World Bank, Migration and Brain Drain, 97).

This fact more actively used by right-wing and centrist parties, which launched the slogan "Veniți acasă! "(Let’s return home!) At the same time, the Socialist Party, which dominates the left-wing, focused its electoral slogans even more on migration issues, issuing a series of campaign materials calling for a vote "to have the opportunity to work in Russia". With a large part of the country's population abroad for a long time, the "migration issue" is becoming a very serious issue that is on the agenda of the majority of Moldovan political parties. This phenomenon was particularly acute during the parliamentary elections in Moldova on 30 November 2014 and the last parliamentary elections held on 24 February 2019. Thus, during the election campaign, the Party of Socialists of the Republic of Moldova, positioning itself as a pro-Russian political force, announced the existence of an agreement with the bodies of the Federal Migration Service (FMS) of Russia on the amnesty of Moldovan migrants. According to this statement, Moldovan labor migrants in Russia as of November 2014 with any irregularities could freely leave the territory of the Russian Federation and return to Moldova by the date of the elections, and then return to Russia. The pro-European parties perceived this agreement as direct Russian interference in the electoral process in Moldova, explaining this by the fact that Moldovan migrants working in Russia will vote in the elections "not for their real interests, but their place of work". In response, pro-Russian political forces strongly 
criticized the Central Election Committee for opening only three polling stations for Moldovan citizens on Russian territory, accusing it of bias in favor of the current government by limiting the right to participate in elections on political grounds (Macuhin, page 300). Thus, the opinion that the migration preferences of Moldovan citizens are associated with the preferences of purely political citizens has become more and more active.

\section{Conclusions}

This above complex of migration problems in Moldova is also aggravated by the fact that there is no clear answer to the question "how many Moldovan citizens are involved in labor migration, both legal and illegal". This is primarily due to the lack of clarity of the migration registration system in the country as a whole.

Secondly, it is connected with the integration aspirations of the majority of the country's citizens, who increasingly seek to obtain a second (or third) citizenship, most often - Romania, less often - Russia and Italy, both for personal emotional and pragmatic reasons.

The third important factor is the impossibility of technical registration of population migration across most of the eastern border of the state, controlled since 1992 by the administration of the unrecognized "Transnistrian Moldovan Republic". At the same time, there is no even information interaction between the administrative authorities of Moldova and Transnistria on the issues of accounting and statistics of people arriving and departing from the region. This cooperation was carried out with varying degrees of accuracy and efficiency until 2004, was finally discontinued and has not been renewed until today (the article was written between February and March 2020).

The fourth important factor is the systematic nature of the direct dependence of the Moldovan economy as a whole on a significant level of financial flows generated mainly by Moldovan labor emigrants. At the moment, taking into account the final statistics for the period of late 2019 - early 2020, we can speak about a certain tendency to reduce this dependence, compared to the period of mid-2000s, when in 2006 the volume of official transfers only constituted 35\% of the country's GDP. However, even the current level of $15-17 \%$ of official remittances compared to the GDP of the country leaves Moldova in the TOP-20 countries of the world most dependent on remittances, which are carried out, first of all, by migrant workers. Moreover, the fact that the level of migration from Moldova is generally increasing rather than 
decreasing, while the growth rate of the Moldovan economy over the last few years remains stably low, in the region of 3-4\%, cannot but cause concern. A comparison of the migration rate (even taking into account the problems of accounting and statistics described above) allows to conclude that the comparative level of dependence of the Moldovan economy on Moldovan labor migrants has not changed and remains stably high today (end 2019 - beginning 2020). For example, the Moldovan media periodically discuss attempts to assess the real level of emigration from the country - it actively discusses various indicators of migration of Moldovan citizens - from 400 thousand to more than one million migrants, which is additionally used as a speculative factor, including in the political programs of various parties.

And finally, none of the currently functioning big and social representative political parties in the Republic of Moldova offered its detailed program to overcome the permanent migration crisis, which threatens to completely devastate the country and, as a consequence, highly likely may become a key factor for future development the socio-economic collapse by $2035-2040$.

\section{References}

Center of the Journalistic Investigations. 2008. Work and Travel in USA - benefit to one side, but a nightmare to another https://www.investigatii.md/ro/investigatii/economic/summer-worktravel-in-usa-profit-pentru-unii-cosmar-pentru-altii [accessed on: 14.12.2020].

Cojuchari Ecaterina. 2018. "How Moldova became home to different peoples. Part One - Jewish Town”. Newsmaker.md, March 12, 2018, https://newsmaker.md/rus/novosti/kak-moldovastala-obshchim-domom-dlya-raznyh-narodov-chast-pervaya-evreyskoe-meste-38170/ [accessed on: 7.11.2020].

Fomenko Vitaliy, Krivenko Andrei. 2012. Problems of population migration in Transnistria, in: Proceedings of the II International scientific-practical conference "Problems of sustainable development of the Republic of Belarus and neighboring countries", Mogilev, State University named A.A. Kuleshov, 266-270.

Glebov Victor, Macuhin Alexandr. 2015. To the question of the results of the parliamentary elections on November 30, 2014 in the Republic of Moldova, in: Innovation in the modern world, Moscow, GNTY, 298-303.

International Bank for Reconstruction and Development. 2019. Migration and Brain Drain. Europe and Central Asia Economic Update, Washington, DC, https://openknowledge. worldbank.org/bitstream/handle/10986/32481/9781464815065.pdf [accessed on: 12.11.2020]. 
Infotag.md. 2016. In 2015, 2236 of Moldavian citizens left home country for permanent residence abroad http://www.infotag.md/m9_populis/225192/ [accessed on: 14.12.2020].

Macuhin Alexandr. 2017. Emigration from the Republic of Moldova in the period 1991-2015. Positive and negative aspects of the process, in: Wspolczesne Problemy Obszaru Postradzieckiego. Procesy polityczne na obszarze postradzieckim, Bydgoszcz, Wydawnictwo Universytetu Kazimierza Wielkiego, 314-331.

Ministry of Internal Affairs of Republic of Moldova. 2017. Statistical Compendium of the Extended Migration Profile of the Republic of Moldova for the years 2014-2016, Chisinau. http://bma. gov.md/sites/default/files/media/cs_pme_2017.pdf [accessed on: 12.11.2020].

Mosneaga Vitalie. 2009. "Population of Moldova in the context of modern migration processes", in: Moldova - Transnistria: Working together for a successful future, Chisinau, USM, 156-172.

Mosneaga Vitalie. 2010. Crisis economic: case study Republic of Moldova, in: Premizele dezvoltarii economiei nationale in contextual crizei economice. Materialele conferintei stiintifico-practice international, Balti.

Mosneaga Vitalie, Corbu-Drumea Luminita. 2010. Migrația în / din Republica Moldova: proces şi reglementare, Iasi, Captes, 239-251.

National Bank of Republic of Moldova. 2020. Money Transfers from Abroad in Favor of Individuals (gross basis). https://www.bnm.md/bdi/pages/reports/dbp/DBP14.xhtml?id=0ang=en [accessed on: 12.11.2020].

Newsmaker.md. 2019. Since independence, 1 million people have emigrated from Moldova. About $40 \%$ of them are people with higher education. https://newsmaker.md/rus/novosti/iz-moldovyemigriroval-1-mln-chelovek-pochti-polovina-iz-nih-lyudi-s-vysshim-obrazovaniem/ 10.10.2019 [accessed on: 15.12.2020].

Pantiru Maria, Black Richard, Sabates-Wheeler Rachel. 2007. Migration and Poverty Reduction in Moldova. Sussex, University of Sussex: Sussex, https://assets.publishing.service.gov.uk/ media/57a08c0840f0b652dd001084/WP-C10.pdf [accessed on: 11.11.2020].

Poalelungi Olga. 2010. "Moldova in the flow of international migration" in Main challenges to demographic security: similarities and differences in Moldova and Belarus, ed. Paladi Gheorghe and Shakhotko Liudmila, Chisinau, Stiinta, 275-279.

World Bank Group. 2018. Migration and Development Brief\#29. Recent Developments and Outlook. https://www.knomad.org/sites/default/files/2018-04/Migration\%20and\%20Development\%20 Brief\%2029.pdf [accessed on: 15.12.2020]. 